\title{
Factors Associated with use of Emerging Technologies at Secondary School level in Khyber Pakhtunkhwa, Pakistan
}

\author{
Dr. Sajjad Hayat Akhtar \\ Teacher Provincial Education Department (Khyber Pakhtunkhwa) Pakistan \\ Irfan Ullah \\ Lecturer, Department of English, Abdul Wali Khan University Mardan Pakistan \\ Dr. Hamida khatoon \\ Professor Jinnah University for Women Karachi
}

DOI: $\quad 10.6007 /$ IJARBSS/v4-i2/668 URL: http://dx.doi.org/10.6007/IJARBSS/v4-i2/668

\section{ABSTRACT}

The study looked into descriptive research to evaluate the emerging trends and use of Emerging technologies at secondary school level in Khyber Pakhtunkhwa (Pakistan). It has defined the emerging trends, problems, needs, usefulness and status of emerging technologies. The main objectives of the study were, to determine the role of emerging technologies, needs, usefulness, status and emerging trends of emerging technologies at secondary school level. The following results were drawn by the researcher in the light of the analysis of the data. The focus of varied emerging technologies revealed that radio and television are not accessible as a medium of instruction in rural as well as urban areas. It was found that the teachers do not make effective use of emerging technologies in rural areas. It was observed that the emerging technologies are not available for technical subject both in rural as well as urban areas. Beside, computer mediated communication is not used for counselling and science subjects both urban as well rural areas.

KEWORDS: Emerging Technologies

\section{Introduction}

Education, in general, and higher education in particular, currently faces increasing demands for more effective educational experiences by the students, in face of dimensioning per students financial resources available to support this educational task.

The demand for effective form of education requires the use of a great verity of methods in formal education. The use of modern educational technology offers the potential for meeting a number of challenges in addition to an increase in productivity. Unfortunately, improvement the delivery of university level education has been quite slow, even though some important tools like overhead projectors and slide projector, tape recorders and television equipments have not been introduce in to educational institution, the basis form of teaching remains the traditional lecture. 
Venkataiah (1996, p.2) stated that:" The word technology the (The Latin form is texere, to weave or build) does not necessarily imply the utilization of machines, as a large number seem to think, but to any practical art utilizing scientific knowledge".

Solomon (2000, p.5) stated that: "Technology is the set of equipments and skills while are utilised to fulfil the needs of the community. Technology describes a process that is something that people do to solve problems or to achieve objectives and products such as instruments and tool, something that can be touched and exists and can be utilized to satisfy the community needs."

\section{Literature}

Educational technology is the application of scientific principles to education and also lays stress on the development of methods and techniques for effective teaching learning. Educational technology emphasises the organisation of learning situations for the effective realisation of the goals of education.

.Educational technology covers two aspect in teaching learning process i.e. technology as a things and technology as a social process. Educational technology is the embodiment of the practical information which is the out come of the application, science of teaching and learning to observe it practically in the classroom together with the aids and teaching strategies developed to give a feed back in its application.

Venkataiah (1996, pp. 3, 4): "The forecasting regarding the effect of technology on education has been slow to mature. This is mainly due to the field itself has been altering in response to outside pressure of late; the instructional system technology has been developing quickly. If any professional field is going to stay viable and continue to develop, it must be responsive to its competition and its customers E.T is no exception." Venkataiah $(1996$, p.4) said "If we look into the history of ET for the last 50 years especially in developed states like USA, it is evident that every ten years ten years have seen the introduction of at least one new communication technology, which was forecasted to radically to radically transform informational and instructional communication. The new communication technology introduced in the 50 was film; Broadcast educational television, audio-visual aids such as film strips, slides, and observed transparencies and programmed instruction were introduced in 60s, in the 70s, video cassettes, remote access audio and video and computer assisted instruction were introduced. In $80 \mathrm{~s}$, the new communication technology introduced was video tax, interactive video, teleconferencing, electronic mail and artificial intelligence i.e. computer memory."

Just like other aspects of educational process, educational technology provides assistance to the process of curriculum development. Rashid M. (1998, p.45) elaborate that: "The traditional teachers depended too much on verbal exposition. The pupil hears and forgets. But how it is possible to see and do every thing in the classroom? Although it is very difficult, but educational technology makes it possible. With the help of electronics, teaching and learning can be enriched and a number of scenes may be shown in the classroom in a short time which is impossible to see in actual position for every one."

According to Jagannath Mohanty (1992, p. 24): 
Educational technology is not just the electronic media; it is only a component of the whole and one of the constituents, which constitutes educational technology. Stress is being laid on the electronic media or the big media such as television, video, films, computers etc. All the financial resources and manpower are in hand or spent on these glamorous and attractive technologies. Orthodox and non-projected aids such as print media, material, models, charts, flannel board, even radio, slides, film strips, transparencies are important parts of educational technology and in the developing states like India these are rather suitable technology which wants special stress on high priority in this connation."Just like other aspects of educational process, educational technology provides assistance to the process of curriculum development. Rashid M. (1998, p.45) stated that:

"The traditional teachers depended too much on verbal exposition. The pupil hears and forgets. But how it is possible to see and do every thing in the classroom? Although it is very difficult, but educational technology makes it possible. With the help of electronics, teaching and learning can be enriched and a number of scenes may be shown in the classroom in a short time which is impossible to see in actual position for everyone."Venkataiah (1996, p.17):"The teacher has to play a fundamental role for the success of the Educational Technology The teaching aids either new or old just supplement the attempts of the teacher to improve the learning process. ET cannot be a substitute for the instructor. The technologies help him to perform his duty in an efficient way to achieve the educational goals."

The usual explanation for ET is that it will take the place of teacher and the result will be unemployment. No technology can give new thing because out put is dependent upon the nature of in put. The input side is more necessary and it is dependent on educator the instructional material cannot be made by ET therefore, ET will not replace the human teacher but will assist him in improving teaching learning processes.

Moore (2004) says that through a training the "teachers are trained in the acquisition of certain competencies related to aspects of classroom management, long-term medium-term and short-term planning, recording and reporting students' work leading to the achievement of prescribed, assessable and (presumably) acquired-for-life 'standards'". Prime purpose of any sort of teachers training activity is to improve capacities of the individuals for making them most suitable and fit for the teaching assignment. It is a fact that teaching qualities cannot bring overnight changes but training activity acts as a source of reorientation, which helps the trainees to improve their capabilities. It has been observed that the teachers having adequate training on their credit usually produce better results and improved achievement of the students, whereas according to Jafri \& Shahzadi (2002) "untrained teachers can cause undue disturbance in the educational system for not being properly equipped with modern knowledge and latest regarding the educational methods."

\section{Objectives}

Objectives of the study were to:

1. Evaluate the position of Emerging technologies at secondary level in Khyber Pakhtunkhwa.

2. Determine the usefulness of Emerging technologies at secondary level in Khyber Pakhtunkhwa. 
3. Identify the significance of the use of Emerging technologies at secondary level in Khyber Pakhtunkhwa.

4. Point out the effectiveness of Emerging technologies at secondary level in Khyber Pakhtunkhwa.

5. Assess the emerging trends of Emerging technologies at secondary level in Khyber Pakhtunkhwa.

\section{Methodology}

Data was collected through survey and questionnaires. The researcher administered two different self assessment questionnaires and sampled principals, and Senior School Teachers at Secondary School level in 6 districts out of 24 districts of Khyber Pakhtunkhwa province (Pakistan) i.e. Abbottabad, Battagram, Charsadda Haripur, Mansehra and Mardan. For demographic profile percentages were used to compare the frequencies of the responses. Chi Square was applied to measure the role, needs, impact and effectiveness of Educational Technology at secondary school level. Heads of the schools, SSTs, and GHS, GGHS total population 1,2, and 3 were taken as a sample 1,2 and 3 i.e. $30 \%, 30 \%$, and $30 \%$.

Result

The following results were presented after the data were analyzed statistically.

Table No: 1 Opinion of principals regarding the emerging trends and use of educational technology.

\begin{tabular}{|l|l|l|l|l|l|l|l|}
\hline S.No & \multicolumn{1}{|c|}{ Statement } & SA & A & UNC & DA & SDA & X2 \\
\hline 1 & $\begin{array}{l}\text { You have possessed skills in the } \\
\text { use of emerging technologies. }\end{array}$ & 46 & 39 & 4 & 0 & 1 & 113.01 \\
\hline 2 & $\begin{array}{l}\text { You have Knowledge of emerging } \\
\text { technologies resources and the } \\
\text { organization dealing with it. }\end{array}$ & 52 & 33 & 2 & 2 & 1 & 121.22 \\
\hline 3 & $\begin{array}{l}\text { Emerging technologies have } \\
\text { proved to increase intellectual } \\
\text { level of the teachers. }\end{array}$ & 27 & 39 & 19 & 2 & 35.78 \\
\hline 4 & $\begin{array}{l}\text { You faced problems in having } \\
\text { access to emerging technologies. }\end{array}$ & 14 & 45 & 18 & 6 & 7 & 56.11 \\
\hline
\end{tabular}




\begin{tabular}{|c|c|c|c|c|c|c|c|}
\hline 5 & $\begin{array}{l}\text { You are facing Problems of } \\
\text { improper planning for the } \\
\text { utilization of emerging } \\
\text { technologies at secondary level. }\end{array}$ & 9 & 36 & 28 & 7 & 10 & 38.34 \\
\hline 6 & $\begin{array}{l}\text { Emerging technologies have } \\
\text { helped teachers to include latest } \\
\text { information regarding } \\
\text { instructional materials. } \\
\text { Emerging technologies has } \\
\text { improved the quality of } \\
\text { instructional materials in the } \\
\text { teaching learning process. }\end{array}$ & 48 & 36 & $\begin{array}{l}13 \\
-\end{array}$ & 5 & 4 & 73.78 \\
\hline 8 & $\begin{array}{l}\text { Computers have promoted the } \\
\text { habits of learning by doing. }\end{array}$ & 33 & 24 & 19 & 3 & 11 & 29.78 \\
\hline 9 & $\begin{array}{l}\text { Computers have involved more } \\
\text { senses for effective teaching } \\
\text { learning process. }\end{array}$ & 35 & 29 & 13 & 7 & 6 & 38.89 \\
\hline 10 & $\begin{array}{l}\text { You has have related refresher } \\
\text { training You regarding emerging } \\
\text { technologies. }\end{array}$ & 46 & 23 & 12 & 5 & 4 & 67.23 \\
\hline 11 & $\begin{array}{l}\text { You need in-service training to } \\
\text { develop management skills. }\end{array}$ & 29 & 52 & 5 & 4 & 0 & 109.22 \\
\hline 12 & $\begin{array}{l}\text { You can evaluate the performance } \\
\text { of their eclogues better by }\end{array}$ & & & & & & \\
\hline
\end{tabular}




\begin{tabular}{|c|c|c|c|c|c|c|c|}
\hline & training. & 39 & 37 & 4 & 7 & 3 & 74.67 \\
\hline 13 & $\begin{array}{l}\text { In-service training helps the head } \\
\text { of the institutions to deal better } \\
\text { with the student's demands. }\end{array}$ & 35 & 33 & 12 & 7 & 3 & 49.78 \\
\hline 14 & $\begin{array}{l}\text { The training should always be } \\
\text { linked day to day functions of the } \\
\text { heads of the institutions. }\end{array}$ & 39 & 31 & 11 & 8 & 1 & 58.23 \\
\hline 15 & $\begin{array}{l}\text { Heads of the institutions must be } \\
\text { capable of identifying the needs of } \\
\text { emerging technologies. }\end{array}$ & 33 & 33 & 17 & 7 & 0 & 49.78 \\
\hline
\end{tabular}

It is observed from the above analysis that the calculated value of Chi Squire (65.75) is greater than the table value of $\times 2=9.488$ at $P=0.05$.So as a whole the result is significant .Therefore, it is supported the statements that the principals faced problems in having access of emerging technologies and have no related refresher training regarding emerging technologies.

Table No: 2. Opinion of Teachers about the emerging trends, usefulness and status of emerging technologies:

\begin{tabular}{|l|l|r|r|r|r|r|l|}
\hline S.No & \multicolumn{1}{|c|}{ Statement } & SA & A & UNC & DA & SDA & Total \\
\hline 1 & $\begin{array}{l}\text { Emerging technologies can } \\
\text { be useful for motivational } \\
\text { purpose. }\end{array}$ & 125 & 276 & 56 & 42 & 19 & 418.89 \\
\hline 2 & $\begin{array}{l}\text { Students are interested to } \\
\text { learn through emerging } \\
\text { technologies. }\end{array}$ & 98 & 262 & 52 & 55 & 51 & 317.7 \\
\hline 3 & \begin{tabular}{l} 
Computer provided \\
\hline
\end{tabular} & 90 & 242 & 75 & 83 & 28 & 253.85 \\
\hline
\end{tabular}

IJARBSS - Impact Factor: 0.305 (Allocated by Global Impact Factor, Australia) 


\begin{tabular}{|c|c|c|c|c|c|c|c|}
\hline & $\begin{array}{l}\text { theoretical and practical } \\
\text { learning activities. }\end{array}$ & & & & & & \\
\hline 4 & $\begin{array}{l}\text { Computer provided } \\
\text { advance instructional } \\
\text { practices for remedial } \\
\text { teaching and learning. }\end{array}$ & 140 & 156 & 71 & 77 & 74 & 64.84 \\
\hline 5 & $\begin{array}{l}\text { Computers have promoted } \\
\text { the attitude of learning by } \\
\text { doing. }\end{array}$ & 139 & 230 & 65 & 42 & 42 & 253.96 \\
\hline 6 & $\begin{array}{l}\text { Computers network are } \\
\text { expensive to develop for } \\
\text { students. }\end{array}$ & 95 & 99 & 93 & 153 & 78 & 31.88 \\
\hline 7 & $\begin{array}{l}\text { The programs presented } \\
\text { through computers were } \\
\text { effective. }\end{array}$ & 74 & 143 & 105 & 117 & 79 & 31.03 \\
\hline 8 & $\begin{array}{l}\text { Internet has developed the } \\
\text { chances of having latest } \\
\text { information for students in } \\
\text { the related areas. }\end{array}$ & 41 & 146 & 131 & 117 & 83 & 68.26 \\
\hline 9 & $\begin{array}{l}\text { Internet has capable } \\
\text { students to gain advance } \\
\text { learning experiences. }\end{array}$ & 59 & 180 & 87 & 120 & 72 & 90.44 \\
\hline 10 & $\begin{array}{l}\text { ETV has promoted two- } \\
\text { way communication for } \\
\text { positive learning. }\end{array}$ & 94 & 119 & 80 & 163 & 62 & 59.32 \\
\hline
\end{tabular}




\begin{tabular}{|c|c|c|c|c|c|c|c|}
\hline 12 & $\begin{array}{l}\text { ETV has covered the vas } t \\
\text { areas for providing latest } \\
\text { information to students. }\end{array}$ & 135 & 153 & 72 & 112 & 46 & 75.42 \\
\hline 13 & $\begin{array}{l}\text { In-service training of } \\
\text { emerging technologies } \\
\text { should be arranged every } \\
\text { year. }\end{array}$ & 70 & 130 & 73 & 164 & 81 & 66.81 \\
\hline 14 & $\begin{array}{l}\text { In-service training of } \\
\text { teachers regarding } \\
\text { emerging technologies is } \\
\text { very important at } \\
\text { secondary level. }\end{array}$ & 81 & 139 & 87 & 112 & 99 & 20.57 \\
\hline 15 & $\begin{array}{l}\text { Teachers can improve the } \\
\text { efficiency of their work by } \\
\text { improving their all } \\
\text { professional skills. }\end{array}$ & 135 & 153 & 72 & 112 & 46 & 75.42 \\
\hline
\end{tabular}

It is observed from the above analysis that the calculated value of Chi Squire(121.89) is greater than the table value of $\mathrm{x} 2=9.488$ at $\mathrm{P}=0.05$.So as a whole the result is significant .Therefore, it is supported the statements that the teachers faced problems in having access of emerging technologies and students are interested to learn through computer.

\section{Conclusion}

It revealed the pivotal role of emerging technologies in the process of education. More importantly a great contrast in the use of emerging technologies in KPK was noted, which suggested a strong need for improving the status of emerging technologies in the province especially in the rural areas.

1. It was discovered that emerging technologies is not accessible to students in rural areas.

2. The focuses of varied emerging technologies revealed that radio and television are not accessible as a medium of instruction both in rural as well as urban areas.

3. It was found that the teachers did not make effective use of emerging technologies in rural areas.

4. It was discovered that the emerging technologies is not available for technical subjects both in rural as well as urban areas. 
5. It was found that teachers are not using audio cassettes for drama, documentaries and group discussion both in rural as well as urban areas.

6. The study identified that computer is not available both in rural as well as urban areas.

7. It was found that computer medicated communication is not available as a medium of instruction both in rural as well as urban areas.

8. It was also revealed that internet is not available both in rural as well as urban areas.

9. It was found that computer mediated communication is not use for counselling and science subjects both in urban as well rural areas.

10. It was found that over head projector is not using both in rural as well as urban areas.

11. The students were confronted with the problems that the teachers do not use flash cards, felt boards, static models, sectional models, slides, opaque projectors and models both in rural as well as urban areas.

12. In the same way that the syllabus is frequently being revised both in rural as well as urban areas.

13. It was also found that the teachers have no chances for refreshers courses both in rural as well as urban areas.

14. It was discovered that enough places are not available for the use of emerging technologies.

15. It was discovered that the educational exhibition are not frequently arranged both in rural as well as urban areas.

16. There is a wide spectrum of issues that inadequate coordination between teachers and students and lack of the participation of the teachers and principals in policy making has limitized the efficiency of the teachers to develop secondary school education.

17. The study identified that there is lack of provision of advice and help to develop effective study skills, the absence of two way communication between students and teachers and lack of creativity in teachers.

\section{Recommendations}

Keeping in view the constraints due to in-adequate emerging technologies facilities the researcher makes a few general recommendations. The researcher is firm in his belief that: if the existing in-adequate resources are optimally utilized and efficient management is corrected; the motivation for innovation would start within rural as well as in urban areas' schools themselves.

1. Emerging technologies accessibility may be ensured in all the secondary school in KPK.

2. Radio, television, computer and internet may be provided to each school.

3. Emerging technologies may be provided for technical subjects.

4. Computer mediated communication should be ensured.

5. Emerging technologies may be used effectively.

6. Audio cassettes may be used for drama and documentaries.

7. Computer mediated communication should be used for counselling and science practical.

8. Over head projector should be used in teaching learning process.

9. Flash cards, felt boards static models, overhead projectors, sectional models, slides, opaque projectors and models should be used in teaching learning process both in rural as well as urban. 
10. Enough places may be provided for the use of emerging technologies.

11. Emerging technologies should be provided for technical subjects.

12. Teachers may be sent their recommendations about the subjects to higher authorities.

13. Refresher courses should be arranged both for rural as well as urban areas teachers.

14. Educational exhibition should be arranged both for rural as well as urban areas.

15. Adequate coordination between teachers and students may be established both in urban as well as rural areas.

16. Teacher's and principal's participation should be ensured in policy making.

17. The provision of trained emerging technologies teachers may be ensured.

18. A continuous system of curriculum may be introduced at secondary level in accordance with the national needs, market demands and capabilities of students.

19. The sufficient budget should be allocated for emerging technologies.

20. The Head of the institutions should be authorised to purchase emerging technologies equipment.

21. Television channel should be launched for secondary students.

22. Computer must be made compulsory for each student.

23. Computer subject may be included as a compulsory subject at secondary level.

24. Student's advisory services must be provided to each student at secondary level.

25. All the elements of instructional technology should be ensured in each and every school.

\section{References}

Best W.J and khan J.V (1989) Research In Education, Sixth Edition, New York Prentice Hall. Govt. of Pakistan (1999) District Census Report of Abbottabad Publication No.32.

Govt. of Pakistan (1999) District Census Report of Battagram Publication No.45.

Govt. of Pakistan (1999) District Census Report of Charsadda Publication No.28.

Govt. of Pakistan (1999) District Census Report of Haripur Publication No.55.

Govt. of Pakistan (1999), District Census Report of Mansehra Publication No.33.

Govt. of Pakistan (1999) District Census Report of Mardan Publication No.106.

Gay L.R (1999), Educational Research, Fifth Edition, NBF $2^{\text {nd }}$ Reprint, Pakistan, Fine Books Printer Lahore.

Govt. of KP (2008) Educational Management Information Centre Provisional Education Department Peshawar.

Jafri, H., \& Shahzadi, S. (2002). Comparison between untrained teachers and achievement of students at Secondary level, Lahore: Unpublished master thesis, University of the Punjab. 
Mohanty. J (1992), Educational Technology Deep \& Deep New Delhi.

Moore, A. (2004), The good teacher: Dominant discourses in teaching and Moore,A. (2004), The good teacher: Dominant discourses in teaching and teacher education. London: Routledge Palmer education. London: Routledge Palmer

Rashid, M.(1998), Educational Technology, Islamabad National Book foundation

Solomon D.L. (2000), Towards a post modern agenda in instrucational technology.Educational Technology Research and development..

Venkataiah N. (1996), Educational Technology, APH Publishing Corporation Daryaganj New Delhi. 